\title{
The Development of Medicine Voiced Ball (MVB) in Learning Big Ball Games for Special Needs Students
}

\author{
Sukendro \\ Department of Sport and Health Education, Faculty of Sport Science, Universitas Jambi, Indonesia \\ *Corresponding author. Email: sukendrodasar@yahoo.co.id

\begin{abstract}
Big ball games are one of the most popular sports and every human likes to do. The purpose of this research is to produce ball that will be named "Medicine Voiced Ball (MVB)"; how to manufacture MVB on visual abilities in children who include blind people. MVB will be able to represent ball characteristics that are expected to be used in blind children. This Research and Development study produces a prototype product "Medicine Voiced Ball (MVB)", with four test cycles; the first cycle of the ball with color and sound with small size, the second cycle of small balls with color, soft and the sound is taped outside, the Third Cycle of basketball with the sound outside, the fourth cycle of large softball balls. The conclusion is MVB can be used for special needs students. It will be advanced research using high technology MVB with an innovative breakthrough and answer the special issue of special ball fulfillment for children with special needs visual impairment.
\end{abstract}

Keywords: Medicine voiced ball (MVB), learning big ball games, special needs students

\section{INTRODUCTION}

One of the major problems in physical education in Indonesia to date is the ineffectiveness of teaching physical education in schools especially in schools for students with special needs. This is due to several factors among which are less creative teachers of physical education and limited resources used to support the process of teaching physical education both in facilities and infrastructure that support the learning process appropriate for students with special needs.

Therefore, the need to modify the sport in the form of science and technology as an alternative in the teaching of physical education is absolutely necessary. Teachers are required to be more creative, innovative in creating learning, which will be given to students, so to create active learning for students, or fun without leaving the learning objectives. Many factors affect student learning outcomes, one of which is the lack of creative physical education teachers in creating and developing simple learning media, using methodology or teaching styles that students and teachers need less learning models so that the learning process is less interesting for students.

It is clear from the description that the learning process becomes ineffective, and consequently that the expected quality of movement is very low. Modification of physical education can be done with emphasis on various aspects such as material, tools, field size, shape, number of players. By modifying media or aims tool to improve learning outcomes, interest or participation of students in following learning, creating a fun learning atmosphere and not boring for students.

From the problems described, the researchers will pour creativity to make learning strategies more appealing for special need students, which is to modify the ball that can support the learning path for blind students. The researcher created a special ball aids for children with special needs of the blind. The ball will be named "Medicine Voiced Ball (MVB)".

This study aims to create a large ball prototype that can be used for learning students with special needs blind. The product prototype was named Medicine Voiced Ball (MVB).

\section{METHOD}

This research is a development research that aims to produce a ball product called Medicine Voiced Ball (MVB). According to Borg and Gall in Sugiyono (2009: 9), research and development is a method to develop or validate products that is used in education and learning. This development study uses a procedural development model, because this model is descriptive, that is a procedure that describes the steps that must be followed in producing the product. According to Wasis (2004: 6) in each development can choose and find steps which are most appropriate for his research based on the conditions and constraints faced. Research and 
development seeks to produce a component in the education system through development and validation steps.

\section{Research Procedure}

Procedures or research and development steps should not use standard steps to be followed, but each development can select and determine the most appropriate step for its research based on the conditions and constraints it faces. The procedures used in the development of Medicine Voiced Ball (MVB) for children with special needs visually impaired are as follows:

\section{Product Trial}

This study uses experimental design as a pilot design. This pilot design is conducted through two stages, ie small group testing conducted at one SLB school in Jambi Province, and field test will be conducted at several SLB schools spread over Jambi Province.

The trial subjects are the target users of the product, the students with special needs of the blind in the SLB Jambi Province and some schools in some districts. This try out is done with the intent to find out whether the MVB product can be used to perform the game by students with special needs visually impaired.

The data used in this research are qualitative and quantitative data. Qualitative data is obtained from interviews in the form of criticism, advice from experts orally as well as written as a constructive input for product revision materials. While quantitative data is obtained from pulse taking before and after learning, influence the use of products and games learners.

Instruments used in product development in the form of interviews, observation, questionnaires, documentation, and the students play by using MVB. Interviews are used to locate and collect information systematically and directed from experts and resource persons. Observations are used to determine the state of facilities and infrastructure and the implementation of the learning process of a large ball in the SLB. Questionnaires are used to obtain information from experts to provide input and suggestions about the products produced to determine the quality of the product. Questionnaires used by learners in the form of a number of questions that must be answered by learners with an alternative answer to know the acceptability of the product.

Data analysis techniques used are percentages for analyzing and assessing development subjects in assessing the feasibility, quality, and acceptability of products in the form of data from specific MVBs. Respondents were categorized into three categories, namely: good (Mean Score +1 SD and above), Medium (Mean -1 SD to Mean Score + 1 SD), Less (Mean -1 SD and below) (Sutrisno Hadi 2004: 150).
MVB products are said to overcome obstacles in a large ball game characterized by the results of the average calculation of the quality assessment questionnaire filled by experts. The analysis technique used is descriptive analysis technique in the form of percentage.

\section{RESULTS AND DISCUSSION}

Result Developments

This research produced a technological product that can be a solution in the research problem. The product is a special ball designed to meet the criteria of children with special needs that is blind. Here is a picture of how the product was produced. There are some steps to do this MVB play:

\section{Design}

The first stage, the game is given to meet the needs of children with special needs in the blind should be analyzed through further research so that the elements of game and sports that became the goal can be achieved.

The second stage, the game created will not work if the tool used the ball is not created in accordance with the characteristics of children with special needs of the blind. The special ball will be made to specifications:

It has a large size resembling a medicine ball; this is meant so that the legs on the ball do not pay attention to special techniques. To kick the ball can be struck using the legs up on the knee. It has a sound, it is intended that the blind with the speaker knows the position of the ball. It has bright color; bright colors will be tested using colors that can emit its light like a light traffic. The color is like green or red highlighter, silver, and white. The color of the ball will be tested and manipulated using the technology to get the color that can be accepted by the blind.

Recharging and low air pressure, ball characteristics with reflected power and low air pressure are expected to be more stable so that can be reached by the blind people. Rolling power / short scroll, ball characteristics like this are needed by the blind people so the ball is not too far if kicked. Thus friends or opponents in the game can reach it quickly, so that the effectiveness of the game is achieved.

Having soft material, this special ball material must have a soft material so that the safety element in the game is achieved. The players will be free to play without having to be afraid of the ball like the normal ball game kids.

The third stage, special ball for children with special needs of the blind is given the name "Medicine Voiced Ball (MVB)". 


\section{CONCLUSION}

The prototype product "Medicine Voiced Ball" can be used as a solution in large ball learning for students with special needs visually impaired. The product should be further investigated by involving manufacturers of ball manufacturers so that the accuracy and specification of bias products is feasible and standard is used.

\section{REFERENCES}

[1] Adang, Suherman. (2000). Dasar-Dasar Penjaskes. Jakarta:Departemen Pendidikan Nasional Direktorat Jenderal Pendidikan Dasar dan Menengah Bagian Proyek Penataran Guru SLTP Setara D-III.

[2] Baharuddin dan Esa Nur Wahyuni.(2010). Teori Belajar dan Pembelajaran. Yogyakarta: Ar-Ruzz Media.

[3] Daniel P Hallahan, James M. Kauffaman \& Paige C. Pullen. 2009. Exceptional Learner An INTRODUCTION to Special Education. United States of America : PEARSON

[4] Depdiknas. 2006. Panduan Penyusunan Kurikulum Tingkat Satuan Pendidikan. Jakarta : BSNP.

[5] Juang Sunanto. 2005. Mengembangkan Potensi Anak Berkelainan Penglihatan. Jakarta : Depdiknas.

[6] Pangrazi, Robert P. 2004. Dynamic Physical Education for Elementary School Children.San Fransisco: Benjamin Cummings.

[7] Samsudin. 2008. Pembelajaran Pendidikan Jasmani Olahraga dan Kesehatan SMP/MTs. Jakarta : PT.Fajar Putra Grafika.

[8] Sari Rudiyati. 2002. Pendidikan Anak Tunanetra. Yogyakarta: Fakultas Ilmu Pendidikan UNY.

[9] Sugiyono. 2009. Penelitian Pendidikan. Bandung : Alfabeta.

[10] Sutrisno Hadi. 2004. Metodologi Research Jilid 2. Yogyakarta: Andi Offset.

[11] Suyono dan Harianto. 2011. Belajar dan Pembelajaran. Teori dan Konsep Dasar. Surabaya: Rosada.

[12] Wardani, dkk. 2007. Pengantar Pendidikan Luar Biasa. Jakarta : Universitas Terbuka

[13] Wasis Dwiyogo. 2004. Konsep penilaian dan pengembangan, Lokakarya Metodologi penelitian jurusan kepelatihan olahraga fakultas ilmu keolahragaan unnes. 